\title{
Suffrage, labour markets and coalitions in colonial Virginia
}

\author{
Elena Nikolova ${ }^{\text {ab* }}$ and Milena Nikolova ${ }^{\text {cd }}$ \\ * Corresponding author at: 204 Victoria Road N22 7XQ, London, UK, Nikolova.ele@gmail.com \\ ${ }^{a}$ Central European Labour Studies Institute, Slovakia \\ ${ }^{\mathrm{b}}$ Institute for East and Southeast European Studies (IOS) Regensburg, Germany \\ ${ }^{c}$ Institute of Labor Economics (IZA), Schaumburg-Lippe-Str. 5-9, 53113, Bonn, Germany, Nikolova@iza.org \\ d The Brookings Institution, 1775 Massachusetts Ave NW, Washington, DC 20036, United States
}

\begin{abstract}
We study Virginia's suffrage from the early- $17^{\text {th }}$ century until the American Revolution using an analytical narrative and econometric analysis of unique data on franchise restrictions. First, we hold that suffrage changes reflected labour market dynamics. Indeed, Virginia's liberal institutions initially served to attract indentured servants from England who were needed in the labour-intensive tobacco farming but deteriorated once worker demand subsided and planters replaced white workers with slaves. Second, we argue that Virginia's suffrage was also the result of political bargaining influenced by shifting societal coalitions. We show that new politically influential coalitions of freemen and then of small and large slave-holding farmers emerged in the second half of the $17^{\text {th }}$ and early- $18^{\text {th }}$ centuries, respectively. These coalitions were instrumental in reversing the earlier democratic institutions. Our main contribution stems from integrating the labour markets and bargaining/coalitions arguments, thus proving a novel theoretical and empirical explanation for institutional change.
\end{abstract}

Keywords: Democracy, Suffrage, Colonialism, Bargaining, Coalitions, Virginia

JEL codes: D02, N31, N41, P16 


\section{Introduction}

What drives institutional change? One theory holds that events described as critical juncturessuch as colonisation by different European powers - interacted with differences in geography and factor endowments to determine paths of institutional evolution across countries. For example, high settler mortality, along with the dominance of labour-intensive activities such as mining or sugar growing, may have prompted European colonisers to adopt extractive institutions (Acemoglu et al., 2001). Once in place, such institutions persisted even after independence (Acemoglu et al., 2001; Engerman and Sokoloff, 2000). A second strand of the literature has instead emphasised the role of structural factors. The quality of political regimes has been linked to redistribution pressures arising from income inequality (Acemoglu and Robinson, 2006; Boix, 2003), income per capita (Boix, 2011; Limongi and Przeworski, 1997) and financial openness (Freeman and Quinn, 2012).

Both strands of research imply that fixed or slow-moving variables such as initial conditions or the income distribution determine institutions. How and why then do representative institutions change? No consensus exists concerning whether politicians or ruling elites only extend the suffrage — one proxy for representative institutions - when they face a revolutionary threat by the masses or rather whether may they do so voluntarily. While Acemoglu and Robinson (2006), Aidt and Jensen (2014) and Aidt and Franck (2015) support the former view, Llavador and Oxoby (2005) emphasise that ruling politicians with divided economic interests may willingly adopt democratisation to influence industrial policies, such as developing legal institutions or education. ${ }^{1} \mathrm{~A}$ rise in the value of public goods relative to transfers (Lizzeri and Persico, 2004) or war (Hicks, 2013) may also prompt elites to embrace democratic institutions even when the probability of uprising is low.

In this paper, we offer yet another argument for institutional change. Specifically, building on Nikolova (2017), we hold that elites extend the suffrage to attract scarce migrant labour, an argument also made by Congleton (2011). We extend and address the shortcomings of Nikolova's elite versus labourers perspective by borrowing insights from Congleton's (2011; 2012) constitutional bargaining and coalition-building framework. Specifically, we outline a concrete political mechanism-bargaining among politicians representing economic interests - which leads to franchise law changes. We further propose that the extent of the

\footnotetext{
${ }^{1}$ An extensive and related literature, such as Dougherty and Heckelman (2008) and Grubb (2003) examines the link between economic interests and constitution-making.
} 
bargain in turn depends on different societal coalitions, whose formation is prompted by labour market dynamics.

Our analysis focuses on Virginia in the period from the early-1600s until the American Revolution and uncovers an interesting puzzle. Starting with the first elections in 1619, all adult males could vote (Chandler 1901, pp. 9-10, Hatch 1965, p. 4). ${ }^{2}$ While this generous suffrage regime survived for nearly forty years, its decline began in the second half of the $17^{\text {th }}$ century. Current servants were the first to become disenfranchised. Subsequently, in 1657-8, only taxpaying freemen who were residents of the colony could vote. ${ }^{3}$ In 1670 , the franchise was further limited to householders and freeholders, excluding many former servants who had been unable to acquire land. The arrival of slavery in the late- $17^{\text {th }}$ and early- $18^{\text {th }}$ centuries-which allowed planters to substitute white workers with blacks - coincided with an even further deterioration in representative institutions. In addition to restricting the suffrage to freeholders, regulations related to religion, race and the re-introduced residency restriction substantially limited the number of eligible voters. ${ }^{4} \mathrm{We}$ explore why this happened.

Our argument rests on two propositions. First, following Nikolova (2017), we argue that changes in Virginia's franchise laws can be explained by labour market dynamics. Specifically, in the 1620 s, Virginia adopted a liberal suffrage regime to entice much-needed immigrant labour. Unlike in South America, where colonisers quickly acquired wealth through exporting gold, Virginia's settlers generated profit from the labour-intensive tobacco production. The initially high mortality among the predominantly white English settlers generated an enormous labour demand, which was first addressed by bringing white indentured servants from England and later on by slave labour. In the spirit of previous work by Acemoglu and Robinson (2006), Congleton $(2011 ; 2012)$ and North and Weingast (1989), we argue that in this early period representative institutions were a credible commitment mechanism ensuring that labourdeprived Virginian planter elites would keep their promises made to poor English migrant workers. Liberal suffrage regimes prevented migrant exploitation by guaranteeing the fair

\footnotetext{
${ }^{2}$ Since no women or slaves could vote, in this paper we consider suffrage extensions or contractions among different classes of mostly white males. Note that the liberal institutions in Virginia took root despite the high mortality, which contradicts Acemoglu et al.'s (2001) prediction that such environments would lead to extractive institutions.

${ }^{3}$ Note that the term "freemen" refers to Virginian settlers who did not come as indentured servants but rather paid for their own passage and were usually landholders. (Wertenbaker, p. 36, p. 40, p. 73). After serving their terms, former indentured servants became freemen.

${ }^{4}$ Note that despite the restrictions, the Virginian suffrage regime was unusually broad and much more liberal than what it would be in Europe until the $19^{\text {th }}$ century (Congleton, 2011, p. 522). For a detailed summary of the evolution of suffrage restrictions in Virginia, see McKinley (1905, pp. 17-47) and Brown and Brown (1964, pp. 125-135).
} 
enforcement of indenture contracts and the payment of freedom dues once the servant term was completed. Following a decline in settler mortality (which led to an increase in labour supply) and the passage of tobacco trade restrictions by England (which led to a reduction in labour demand) in the second half of the $17^{\text {th }}$ century, the franchise was curtailed. Representative institutions - as proxied by suffrage laws — crumbled completely once Virginia's planters were able to replace white workers with slaves in the late- $17^{\text {th }}$ and early- $18^{\text {th }}$ centuries. ${ }^{5}$

However, labour dynamics only explain one part of the puzzle, namely that liberal suffrage laws were adopted in the early- $17^{\text {th }}$ century to entice white immigrants from England. Nevertheless, this argument has several shortcomings. First, it is unclear how exactly landholders' economic interests related to labour market issues translated into political outcomes concerning suffrage laws. Second, the labour market proposition fails to clarify why those from whom the franchise is taken away would not rebel and demand their rights back. Finally, while the overall suffrage restriction trends are consistent with the labour market story, franchise laws became more liberal on several occasions, which suggests that representative institutions are volatile and reversible, or possibly driven by factors other than labour issues.

Our second proposition directly addresses the limitations of the labour market hypothesis. First, we argue that suffrage law changes were due to bargaining among political actors representing economic interests. Bargaining occurred within the elected chamber of Virginia's government (the Assembly), as well as among the Assembly, the governorrepresenting the King - and the governor's council, each of whom had a stake in Virginia's economy. Second, the success and extent of the bargaining depended on the political clout of coalitions formed in society, an argument in the spirit of Stasavage (2002). We identify three strategic coalitions. In the early- $17^{\text {th }}$ century, when labour demand was high, the tobacco planters - who needed workers to generate profits — sided with migrant labourers seeking legal protection from exploitation, resulting in a suffrage regime whereby both freemen and servants could vote. The mid- $17^{\text {th }}$ century saw a decline in labour demand due to increased life expectancy and the imposition trade restrictions, leading to the rise of a new politically influential coalition of larger planters and former servants who were able to acquire land. Facing a subsided pressure to attract migrant labourers, these two groups joined forces to push for restrictions that excluded indentured servants from voting. The arrival of slavery gave rise to a new alliance of large- and small-slaveholding farmers in the late- $17^{\text {th }}$ and early- $18^{\text {th }}$ centuries, which was instrumental in further reversing the earlier democratic institutions. Although larger

\footnotetext{
${ }^{5}$ We show that white and black labourers were close substitutes.
} 
farmers also prospered, smaller planters not only kept inequality low but also influenced decision-making through their increased bargaining power. Catering to the demands of this group prompted political representatives-many of whom were planters and merchants themselves - to disenfranchise the landless and only allow freeholders to vote. ${ }^{6}$ As such, our two-part argument enriches the (i) labour market and the (ii) coalition/bargaining perspectives by showing that a framework linking both theoretical views explains institutional change in colonial Virginia.

To test our propositions, we follow a two-pronged analytical strategy. First, relying on detailed historical evidence ranging from Assembly records to data on the quality of wills, we furnish a rich analytic narrative that supports both the labour market and the bargaining/coalitions propositions. As the coalitions and bargaining aspects of our theory are challenging to define and measure quantitatively, we can only econometrically test the labour market hypothesis. As a second step, we exploit unique data on Virginia's suffrage, along with other economic and demographic variables such as inequality and the extent of slavery, collected by Nikolova (2017). Using regression analysis, we show that the share of Virginia's black population-which captures the racial composition of labour markets-is robustly negatively correlated with the extent of the franchise. ${ }^{7}$

Focusing on Virginia has several advantages. First, as the oldest legislative body in English-speaking America, Virginia allows us observe substantial variation in its suffrage regime over a period covering more than 150 years. ${ }^{8}$ Second, in addition to income inequality remaining relatively constant throughout the colonial period, the coalition and labour market shifts that we identify were driven by largely exogenous events, such as English policies and price shifts in the Caribbean. We can thus credibly disentangle the institutional impact of labour markets from that of redistribution demands by the masses linked to income distribution shifts. Third, the single-colony analysis allows us to overcome problems of time-variant cross-unit heterogeneity in the regression analysis. In addition, we can assemble multiple measures of our independent variables, which is difficult in cross-sectional studies. However, since institutional changes happen at the colony level, we must highlight that our empirical identification relies

\footnotetext{
${ }^{6}$ The fact that the freehold requirements for voting were unspecified until the 1730s supports the claim that the small farmers were politically influential.

${ }^{7}$ We show that this effect is robust to alternative estimation techniques (Appendix, Part 2) and to proxying the supply of black slaves with the ratio between slave and sugar prices in the Caribbean (the largest slave market, which set prices for the rest of the New World) (Table 3).

${ }^{8}$ Other colonies gradually adopted Virginia's governance template as they found it advantageous to include a representative element due to labour mobility and yardstick competition among the colonies (Congleton, 2011, pp. 529-530).
} 
only on time-series variation. Despite certain methodological advantages, analysing a colonylevel panel dataset as in Nikolova (2017) cannot reveal the time-variant dynamics that we explore in the analytic narrative. The micro-level analysis combined with the analytic narrative increases our confidence that it is indeed the constitutional bargaining and coalition shifting triggered by labour market changes that drove Virginia's suffrage evolution.

While the contribution by Nikolova (2017) comes closest to our work, the present paper substantially differs from it in several ways. ${ }^{9}$ First, we address the critiques of Nikolova's elite versus labourers argument by precisely specifying the role of the political process and parliamentary actions through which suffrage regimes are altered. Our refined theory elucidates the political bargaining mechanism, which helps to explain fluctuations in the restrictiveness of the franchise. Second, our research relies on a rich analytic narrative furnishing detailed historical evidence to support our two propositions. More broadly, through the analytic narrative we can also pinpoint how the changing motivations, payoffs and behaviour of the actors affected the political equilibrium. Third, our paper utilises a mixed-methods approach following a growing scholarship that has combined rational choice tools with case studies to validate theoretical predictions (Bates et al., 1998).

\section{Theory}

\subsection{Labour markets, commitment problems and economic interests}

Following the original settlement in 1606, Virginia's economy — and the profits of the Virginia Company of London, the private company that controlled it through a royal charter-strongly depended on tobacco exports, which started in 1618. However, large-scale tobacco production was a labour-intensive process requiring a constant supply of mostly unskilled labourers. Unlike

\footnotetext{
${ }^{9}$ We contribute to the broader understanding of the causes of political change in several ways. First, we enrich existing institutional arguments by studying constitutional bargaining as related to economic interests and labour issues. In addition, we overcome the multiple and inherent difficulties involved in measuring regime quality by focusing on a specific political institution, voting rights. Our contribution also stems from combining empirical evidence with the analytic narrative of colonial Virginia. We thus address the still valid concern in Przeworski (2009, p. 295), who points out that often the historical material used to support various theories of suffrage extensions is almost exclusively limited to Western European cases, "with an obsessive focus on the English reform of 1832." We further build on rich political economy work arguing that representative political institutions emerged to credibly constrain elite power (Acemoglu and Robinson, 2006; Congleton, 2011, 2012; Fleck and Hanssen, 2006; North and Weingast, 1989). In the same vein, Keefer (2007) links the credibility of electoral promises in democracies to indicators ranging from fiscal performance to media restrictions, while Glaeser and Shleifer (2005) show that wasteful redistribution may shape the electorate-as well as political and economic performance-via migration. We also complement recent work in economic history emphasising the primacy of migration and labour market structure in explaining long-term economic development across the world (Allen et al., 2012). Arguments connecting the quality of institutions to migration are also made by Bertocchi and Strozzi (2008) (for the case of $19^{\text {th }}$ century European migrants to the New World) and Braun and Kvasnicka (2013) (who focus on suffrage extensions to women in the US in the 1800s).
} 
the Portuguese colonisers, who coerced the local Indians into slavery or the Spaniards, who arranged free Indian labour, the English could not procure such free labour (Klein, 2004, p. 41). Virginia was facing a labour shortage. Until the late-1600s, planters had limited access to black workers, due to the high demand for and high prices of slaves in the Caribbean and the tight regulation of the slave trade by the Crown (Morgan, 1975, pp. 299-300). Moreover, English migrants preferred the temperate climate of the Northern colonies where they could settle with their families, rather than the South's disease-ridden and often deadly environment (McGuire and Coelho, 2011). In addition, the high costs of crossing the Atlantic and the underdeveloped credit markets limited the inflow of English migrants to the colony. ${ }^{10}$

To overcome these obstacles, the Virginia Company promoted indentured servitude, whereby English migrants bound themselves to a colonial landowner for several years in exchange for travel costs. ${ }^{11}$ Freedom dues payable to the servant upon the expiration of the indenture were high and often allowed newly-freed servants to amass sufficient wealth to not only set up a farm but also gain membership of the House of Burgesses, the lower house of Virginia's Assembly (Wertenbaker, 1922, p. 40, pp. 75-80). To attract workers, Virginia promised sizeable land allowances to all free or indentured settlers. ${ }^{12}$ The majority of taxes were also abolished and in 1643 the colonial government suspended debt and tax lawsuits against immigrants (Morgan, 1975, pp. 93-97; p. 209).

Nevertheless, the system of indentured servitude suffered from several commitment problems (Games, 1999, pp. 76-77; Congleton, 2011, pp. 524-527). Landowners could choose to disrespect or alter the agreed-upon contract by passing laws, especially because many masters were also burgesses (Congleton, 2011, pp. 525-527). As servant terms drew to a close, landowners were also more likely to renege on paying freedom dues or extend the indenture time. Once free, the servants also faced the risk of expropriation or excessive taxation of their profits or land grants by the colonial government.

In principle, servants could resolve contract disputes in court, although in practice, the legal system was unfit to protect the migrant workers from exploitation as courts were naturally biased in favour of large proprietors. When servants had to litigate with their masters, the juries were usually dominated by the very men who were being sued (Morgan, 1975, pp. 128-29).

\footnotetext{
${ }^{10}$ In the $17^{\text {th }}$ century, the majority of migrants to Virginia were English, while in the $18^{\text {th }}$ century German and Irish migrants grew in importance (Ward, 1991, pp. 109-116).

${ }^{11}$ Two-thirds to three-quarters of $17^{\text {th }}$ century migrants to Virginia were indentured servants (Galenson, 1984, p. 9).

${ }^{12}$ Anyone who paid his passage received 50 acres and an additional 50 acres for every other person transported at his costs (Billings, 2004, p. 6).
} 
Prohibitive transportation costs made arbitration-seeking back in England or another colony nearly impossible. Thus, credibility issues were particularly salient in the indenture system. A wide suffrage made it less likely that planters would alter contract terms or refuse to pay freedom dues at the end of the indenture, or that colonial governments would expropriate newly-acquired land, property or profits once the servant was free.

Virginia's initially liberal representative institutions were adopted to attract labour and were in the interest of all economic actors. ${ }^{13}$ By inducing poor workers to migrate, liberal political institutions increased the profits from tobacco production, which served the economic interests of small and large landholders, politicians (many of whom were also planters) and the King. By holding politicians accountable to promises made to workers prior to their arrival, representative institutions increase the long-term income of immigrants. Poor workers value the right to vote for purely economic reasons: without it, some masters may renege on their earlier promises. ${ }^{14}$ Political institutions in which the poor are represented thus serve as a credible commitment mechanism (Acemoglu and Robinson (2006), Congleton (2011; 2012), North and Weingast (1989)). ${ }^{15,16}$

Nevertheless, a large body of literature argues that democratic institutions may be costly for the economically and politically powerful due to pressure for redistributive transfers to poor voters, especially when income inequality is high. ${ }^{17} \mathrm{~A}$ broad suffrage may also make it more difficult for those in power to engage in expropriation. As a result, elites face a trade-off between the costs of a democratic regime (due to redistribution and the loss of expropriated income) and its benefits of attracting labour. Autocratic institutions are more likely to take root when the franchise costs are particularly high, while intense labour scarcity makes it more likely that a liberal suffrage regime is adopted. ${ }^{18}$

\footnotetext{
${ }^{13}$ Political participation was an important consideration for colonists. Electoral turnout was high, and candidates' campaigns centred around important issues, such as the regulation of servant contracts (in the $17^{\text {th }}$ century) or tobacco exports (mostly in the $18^{\text {th }}$ century) (Dinkin 1977, pp. 186-187, Kulikoff 1986, pp. 77-79).

${ }^{14}$ Our theory also implies that when the suffrage is tightened, migration flows to the colony should decrease. We show such evidence in Table 1.

${ }^{15}$ See Seghezza (2015) who, among others, offers a reinterpretation of the North-Weingast hypothesis.

${ }^{16}$ One potential objection to this argument is that political institutions are only one among other means of credibly constraining power. The rule of law — which implies an impartial and independent court system — can be used to both effectively resolve contracting disputes, and to force governments to respect private property. However, as we show in the analytic narrative, judges and assemblymen often ruled on disputes in which they themselves were involved, thus limiting court impartiality.

${ }^{17}$ Acemoglu and Robinson (2006), Boix (2003) and Engerman and Sokoloff (2000) provide different reasons for why inequality (and redistribution) may matter for democracy. For counter-arguments, see Ansell and Samuels (2010), Haggard and Kaufman (2012) and Przeworski (2009).

${ }^{18}$ The argument is illustrated in more detail in Nikolova (2017). One of the main assumptions is that at least some of the migrant workers have high re-migration costs, leading to a lock-in effect.
} 
Nonetheless, as noted in the introduction, this elites versus labourers argument is subject to three main criticisms. First, it does not elucidate how landholders translate their economic interests into political outcomes related to suffrage laws. While Nikolova (2017) treats this process as automatic, we argue that it is the result of parliamentary actions, which in turn depend on actors' bargaining power and ability to influence the decision-making process in government. Second, it is unclear why those who lose their voting rights would simply accept such a deprivation and would not rebel. Third, the argument fails to account for the fact that while they progressively became more restrictive, suffrage restrictions became more liberal several times. In the next section, we refine the labour markets theory by adding the elements of bargaining and coalition shifting framework.

\subsection{Bargaining and coalitions}

In the spirit of Congleton's constitutional bargaining and exchange model (2011), we consider franchise laws as the result of negotiations among elected members within the House of Burgesses as well as among the elected burgesses, the appointed governor (representing the King) and the governor's council. We augment this argument by suggesting that the success of the bargaining depended on the political clout of different coalitions in society, formed around labour market issues. The changing bargaining power, interests and interactions among the economic and political actors can also be prompted by changing socio-economic landscapes, technological or ideological shocks (Congleton, 2011).

Virginia's political landscape comprised three main actors, namely the governor and the appointed and elected assemblymen. The governor-typically appointed by and representing the King in England-had substantial powers to convene or dismiss the General Assembly, propose and veto legislation, sign bills into law and appoint important public officials such as auditors, the clerk of the country court, the customs collector and the attorney general. He also appointed a non-elected council (upper chamber) comprising wealthy and influential merchants or large plantation holders, who had a vested economic and political interest in colonial affairs. Nevertheless, the elected burgesses_comprising the lower chamber-were more numerous and powerful than the councilmen as they decided on all financial matters.

The burgesses represented the middle class, namely smaller plantation owners and property holders. The House of Burgesses — which included about 50 representatives, each of whom served for a term of about five years-only served the narrow interests of those who directly elected them rather than all people (Billings 2004, p. 105, p.107). The governor had some influence over the composition of the burgesses by prolonging or dismissing the 
Assembly — comprising the elected and appointed chambers — but in general had little ability to manipulate the elections. ${ }^{19}$

Virginia's early liberal representative institutions were in the interest of all actors: the indentured servants, small and medium tobacco farmers, the wealthy and powerful large planters and merchants, the King and his agent, the colonial governor. Initially, the liberal suffrage regime not only served to attract migrant labour and ensure economic prosperity but was also one way to credibly prevent abuse and ensure the bargaining power of different political actors vis-à-vis one another (Congleton, 2012, p. 6). The General Assembly had the "power of the purse," thus making the governor financially dependent and increasing its bargaining power. The governor's veto and the two chambers kept the balance of power between economic elites and the middle class. This protected the Virginia Company-which had the colonial charter until 1624-and the King from the colonists (Congleton, 2012, pp. 78). Institutional change only occurred if it was in the interest of a substantial proportion of all actors (Congleton, 2011, p. 529). Therefore, suffrage regimes can be seen as the result of bargaining among the different political actors representing economic interests. The extent of the bargaining depended on the different coalitions emerging in society and influencing politics.

Three such strategic societal coalitions-which in turn depended on labour market dynamics-influenced politics and representative institutions. In the early-17 $7^{\text {th }}$ century, Virginia's settlers shared a migrant background and the drive to improve their economic wellbeing. A first group of colonists comprised the poor white English workers with no capital. Young, single and male, they came to Virginia as indentured servants. The second group of immigrants was also young, male and single but socially well-off. These settlers had financial capital and connections in London and established tobacco plantations soon upon arrival. Economic power soon translated into political power, with the General Assembly of 1619 opening opportunities for political activity for the latter group (Billings 2004, pp. 87-89). Motivated by high labour demand, the socially well-off planters joined forces with the poor English migrant labourers whom they needed to generate profits, resulting in a regime in which both freemen and servants could vote. This win-win situation ensured economic prosperity of the tobacco planters and protected the workers from exploitation and arbitrary treatment.

While these actors initially shared similar interests, by the mid- $17^{\text {th }}$ century population growth and increased tobacco production meant economic competition and a plurality of

\footnotetext{
${ }^{19}$ In the 1730s, the emergence of the Speaker of the House as the most influential political figure in colonial affairs marked the culmination of the gradual transfer of political power from the council to the burgesses, which began several decades earlier (Evans, 2009, p. 13).
} 
interests, which were soon transplanted to the political arena. Coalitions in society and factions among the burgesses and councillors began to emerge (Billings 2004, p. 20). The mid-17 century also saw the rise of a coalition of larger planters and newly-freed servants who were able to acquire land. Its emergence coincided with two labour market changes: lower mortality led to an increase in the labour supply, while the 1651 Navigation Act restricted the tobacco trade and reduced labour demand, thus making the importation of indentured servants from England less pressing. The coalition of newly-freed landed servants and larger planters influenced the laws disenfranchising servants. Finally, the late- $17^{\text {th }}$ and early- $18^{\text {th }}$ centuries saw yet another politically influential slave-holding coalition in the face of the smaller farmers who joined forces with the larger planters. The suffrage was subsequently restricted to freeholders. Both the smaller and larger farmers could purchase the now cheaper slaves and were more concerned with issues related to the tobacco trade than with legislation seeking to entice migrants. In what follows, we provide concrete historical examples of the mechanisms behind the political process related to suffrage changes, such as bottom-up input from constituents, bargaining among political actors and the changing coalitions driven by labour market shifts.

\section{Analytic narrative}

\subsection{Labour markets and political developments}

Prior to 1619 , Virginia's political institutions were characterised by arbitrary power by a plural executive and limited scope for political activity (Congleton, 2011, p. 528; McKinley, 1905, p. 19). ${ }^{20}$ This period witnessed frequent quarrels and power struggles among those charged with governing Virginia. The institutional environment changed with the advent of the lucrative tobacco production. More liberal institutions - loosely modelled after those in England-were introduced between 1619 and 1621 to solve the contracting and governance problems outlined above, as well as ensuring economic prosperity. ${ }^{21}$ The governor, the appointed councilmen and

\footnotetext{
${ }^{20}$ According to the 1606 royal charter of the Virginia Company, the King and its appointees were in control of the colony. The 1609 charter shifted legislative responsibility to the Company's council in exchange for payments to the King, who was interested in receiving revenues outside the control of Parliament (Congleton, 2011, p. 523). This example is consistent with the theoretical framework developed above and demonstrates the King's willingness to trade off some control over colonial affairs for financial gain. The 1612 charter further empowered the Virginia Company, which governed the colony through a democratic general court comprising the stockholders in London (McKinley, 1905, pp. 17-18).

${ }^{21}$ The literature shows "a strong if not dominant pressure for electoral reforms" in the English House of Commons already starting in 1614 (Bushman, 1963, p. 34). In 1621, a bill, which turned out unsuccessful, was proposed to broaden the electorate base for the House of Commons to all free men in towns, regardless of their income (Bushman, 1963, p. 37). The main motivation of the supporters of the reform (the anti-Court party) was to change the electoral procedure by widening the electoral base and thus decrease corruption. While it is possible, that this liberal ideology in England influenced in part the adoption of representative institutions in Virginia, we argue in detail in the Appendix Part 3 that the scope for a substantive impact of ideological shocks was limited. First, colonists could decide on their own suffrage and tailor it to their own specific needs, suggesting that developments
} 
the elected burgesses constituted the new colonial government. The governor represented royal interests and as such opposed liberal institutions, unless they had an economic benefit, such as attracting labour. The councilmen represented the wealthy and well-connected plantermerchant elite and strived to amass political and economic power (Billings, 2004, pp. 88-89). ${ }^{22}$ The elected House of Burgesses comprised middle-class planters and merchants. Importantly, at a time when voting in England was limited to a small percentage of property holding males, Virginia granted the franchise to all adult men, including bound labourers. ${ }^{23}$

Nonetheless, a number of factors in the second half of the $17^{\text {th }}$ century made it less beneficial for those holding political and economic power to maintain the liberal political regime. First, increased longevity and declining mortality due to frontier expansion and changes in diet among colonists increased labour supply (Earle, 1979). While life expectancy was still lower in Virginia compared with the Northern colonies, by the mid-1 $7^{\text {th }}$ century life chances had improved and mortality decreased: the proportion of migrants dying in their first year had reduced from five out of six to one in nine by 1648 (Morgan, 2005, pp. 180-182). ${ }^{24}$

Second, starting in 1651, the English Parliament passed a series of Navigation Acts, which limited planters' ability to sell tobacco directly to European merchants and reduced the demand for servant labour (Wertenbaker, 1922, pp. 85-89). Colonial products such as tobacco and sugar could only be shipped to or imported from England and the English colonies, while all goods taken to and from any English colony had to be transported on English ships mainly

\footnotetext{
in England had little traction. Second, migrants to Virginia shared similar political experiences throughout the colonial period. Even though the migrant pool to Virginia in the $18^{\text {th }}$ century changed to include Germans and Irish migrants, these sending countries had even more restrictive suffrage than the Southern colonies. Nikolova (2017) offers additional evidence that the role of culture in shaping colonial suffrage laws was minimal.

${ }^{22}$ By owning on average estates of seven thousand acres, all 148 councilmen were richer compared with the rest of the colonists (Billings, 2004, p. 89).

${ }^{23}$ The 1619 and 1621 proclamations claimed that the burgesses were to be selected by "the Inhabitants" (McKinley, 1905, p. 21). Despite some disagreement about the meaning of "Inhabitants" (summarised by McKinley (1905, pp. 21-22)), it appears that both freemen and indentured servants could initially vote (Chandler 1901, pp. 9-10, Hatch 1956, p. 4). This is also evident from the language used in a 1646 law which made voting compulsory but exempted servants from the fine (Hening 1823, Vol 1, Act XX, pp. 333-334).

${ }^{24}$ Purvis (1999, p. 171) demonstrates that in the period from December 1618 to March $1620,41.3 \%$ of the population of 1,514 had died, and $28.3 \%$ of the deaths were due to disease. During the April 1623-February 1624 period, $22.5 \%$ of the population of 1,646 had died because of some illness. Dysentery and malaria and epidemics of yellow fever, scurvy and plague were responsible for the high mortality (Wertenbaker, 1922, pp. 39-40). While data on life expectancy are spotty, in the late $17^{\text {th }}$ century, male Creoles in York in the 1665-1699 period had a life expectancy of 20.8 at age 20 and 16.4 at age 30, while Creoles in Charles Parish, Virginia before 1730 were expected to live another 20.2 years if male and 17.9 years if female (again at age 30). For comparison purposes, in England in the period 1655-1699, male life expectancy at 30 was 28.4, and that for females was 28.9 (Carr 1992, p. 274). Citing Kevin Kelly's dissertation work based on 62 families, Morgan (2005, p. 162) notes that mean age at death was about 58 for men born 1620-1650, 56 years for men born 1651-80, and about 62 years for men born 1681-1710. Another piece of evidence that disease and mortality decreased in Virginia the second half of the $17^{\text {th }}$ century is the declining number of physicians and the declining number of lawsuits against physicians, identified in county records (Morgan, 2005, p. 182). Longevity and mortality statistics likely improved due to the rising significance of apple orchards and drinking fermented beverages such as cider as opposed to water.
} 
manned by English sailors. In addition, the growing English economy in the last quarter of the $17^{\text {th }}$ century increased the demand for English labour at home, thus leading to an increase in the price of indentured servants and thus a decrease in the number of demanded servants (Klein 2004, p. 42). These developments transformed the former labourer-planter coalition into an alliance between the planters and the newly-freed landed servants. Maintaining a liberal voting regime in which indentured servants could vote was no longer in the interest of this politically influential coalition, resulting in the disenfranchisement of indentured servants.

Towards the end of the $17^{\text {th }}$ century, the dwindling demand for slaves in the Caribbean due to the falling sugar prices, along with the dissolution of the Royal African Company (the English monopoly that regulated the slave trade), led to a sharp increase in the number of black workers in the Southern colonies. While slavery had a limited impact in the Northern colonies, where wheat continued to be grown on small family farms without requiring additional labour, it completely transformed labour organisation in Virginia and the rest of the South. As Figure 1 and Table A1 in the Appendix show, within just two decades, the black population share in Virginia rose from a little more than 5 percent in 1680 to more than one-quarter in 1700 . Simultaneously, the supply of indentured servants decreased. The economic situation in England improved after the Glorious Revolution, which prompted more would-be migrants to stay at home. Servant recruitment also became more difficult, as after 1682 indentures had to be signed by an English magistrate and no one under the age of 14 could be shipped to the colonies without parental consent (Breen, 1973, p. 14).

There were few technological innovations in tobacco growing and while some indentured servants were still needed for specialised agricultural tasks and to oversee plantation work, the majority of workers during this period were slaves. Although planters initially clung to servants, slaves became substitutes by the early- $18^{\text {th }}$ century. As Kulikoff $(1986$, p. 41) explains, by then planters had learned that slaves could be as productive as whites and thus they avidly sought them every time a slave ship arrived. In fact, many slaveowners trained blacks for higher-skilled occupations, such as building or crafts. Slaves were not only cheaper but also well-suited to plantation agriculture due to the substantial returns to scale, the non-seasonal and simple nature of the work and the high ratio of workers to land, which reduced supervisory costs (McCusker and Menard, 1991, p. 239).

The first attempts to restrict voting rights occurred during the Commonwealth period in England (1651-1660), when the House of Burgesses exercised "supreme power" and even selected the governor (McKinley, 1905, p. 29). In short, the burgesses had bargaining power 
and the interests of the medium planters who they represented dominated politics. Therefore, it is unsurprising that the first suffrage abridgement occurred in 1654/5 when voting was restricted to housekeepers (with only one vote per family). This restriction was reversed the following year to include "all freemen" to avoid taxation without representation (Brown and Brown 1964, p. 125). The ideology of the Commonwealth period in England - which aimed at levelling the playing field-possibly influenced this decision in part (Kolp, 1998, p. 40). In 1657-8, the suffrage was limited to resident tax-paying freemen (McKinley 1905, p. 29), with the residency requirement echoing the dominant "stake-in-society" philosophy in England (Brown and Brown, 1964, p. 126).

In 1670, the Assembly-which now included a greater number of wealthier and influential planters-constrained voting rights to the proprietor class (freeholders and householders) (McKinley 1905, p. 30). The language used in the 1670 act targeted newly-freed servants, claiming that they had "little stake in society." The act stated that "all persons who haveing served their tyme are ffreemen of this country who haveing little interest in the country" had few ties with the "endeavour of the publique good" (Hening, 1823, Vol. 2, Act III, p. 280). The document mentioned that the newly-freed servants used their political rights to cause problems during elections rather than to choose representatives. This episode provides concrete support for the argument concerning the shifting economic interests of the new social coalition and the subsequent legislative outcomes.

Despite the short-lived enfranchisement of all freemen (but not servants) in 1676 during the so-called Bacon's Assembly, ${ }^{25}$ the freeholder and householder voting limitation was reintroduced and used for some time (McKinley, 1905, p. 23). In 1684, the House legislated that landholders and property owners could cast a vote (although tenants with life leases were considered freeholders and one could cast a vote in any county in which he owned and leased land) but did not explicitly penalise irregular voting (Brown and Brown, 1964, p. 126; McKinley, 1905, p. 34). In 1699, voting was restricted to freeholders and a penalty of 500 pounds of tobacco awaited irregular voters. Women and minor freeholders were further explicitly excluded. While Quakers were enfranchised in 1699, Catholics were not allowed to vote. The suffrage regime became progressively more restrictive, with the 1705 law reintroducing the residency requirement and a race requirement. Although a small number of free

\footnotetext{
${ }^{25}$ Non-property-holding freemen voted in June 1676 and Bacon's Assembly subsequently restored their voting rights. As a direct response to grievances, the 1670 act prohibiting non-property-holding freemen from voting was repealed, if only for a few months. According to Billings (2004, p. 50, p. 181), Bacon's Rebellion and its aftermath marked a new era of the relationship between "leaders and the led," suggesting that politicians became more aware of the interests of the smaller planters.
} 
blacks were indeed allowed to vote in the $17^{\text {th }}$ century, this policy de facto ended in 1705 . In 1723, free blacks were officially disenfranchised (black slaves had always been prohibited from voting). ${ }^{26}$ At the beginning of the $18^{\text {th }}$ century, Governor Spotswood-who opposed liberal institutions - tried to push for tighter restrictions for voting and office holding but was opposed by the two chambers. A 1736 act introduced yet another change by requiring a minimum amount of freehold for electors but voters were no longer required to be residents. This law was a direct response to election fraud whereby candidates transferred property or gave leases for life for very small rent to increase their electoral base. As these developments show, Virginia's suffrage laws became more and less restrictive several times, suggesting that the political bargain was clearly not irreversible.

\subsection{Economics interests, coalitions and bargaining}

As discussed in the previous subsection, representative institutions originally served the economic interests of all actors. This is supported by the fact that in 1624 all Virginia colonists issued a declaration stating that participation in representative government not only encouraged them to "follow their particular labours with singular alacrity and industry" but also led to the establishment of many new plantations (Perry and Cooper, 1959, p. 49). Therefore, all colonists saw representative government as the key to their economic prosperity. ${ }^{27}$

Furthermore, the evidence shows that migrants clearly considered representative institutions in their moving decision. Chute (1969, pp. 17-18) mentions a group of high-skilled Poles hired by the Virginia Company who decided to settle in the colony because they were enfranchised and made inhabitants. Migrant inflows are also correlated with the restrictiveness of the suffrage. The number of servants arriving in the colony remained high in the first half of the $17^{\text {th }}$ century. In 1635 alone, 2,009 persons left London for Virginia, while in the 1625-1640 period approximately 15,000 new migrants landed in the colony. By contrast, after 1660 the annual migrant in flows dropped to less than half of their peak in 1650-1660 (Games 1999, p.

\footnotetext{
${ }^{26}$ In 1705 blacks, mulattoes and Indians were forbidden to hold any public office and were also de facto deprived from the right to vote (Browne-Marshall, 2013, p. 177). The 1723 law formally excluded free blacks, mulattoes, and Indians from voting in any type of election (McKinley, 1905, pp. 36-37). This restriction was introduced because of the attempted slave insurrection, in which free blacks and mulattoes were suspected of being involved, and the presumption that free blacks would always favour slaves. This law was also passed to make free blacks aware of a distinction between themselves and Englishmen, with whom they would never be equal (Brown and Brown, 1964, p. 128).

${ }^{27}$ One example of the colonists cherishing their right of representation was in 1673 when the King granted the ownership of the colony to the Lords Arlington and Culpepper. The colonists defended their right to representation, arguing that "no manner of impositions of taxes shall be laid or imposed upon the inhabitants and proprietors there, unless by the common consent of the governor, council and burgesses, as hath heretofore used" (McKinley, 1905, pp. 31-32).
} 
21; Table 1). The worsened representative institutions - coupled with the reduced demand for white workers and the difficulty of securing land - prompted those who were no longer allowed to vote to move to other recently-established colonies, such as the Jerseys, Pennsylvania and Delaware, which presented both better economic opportunities and more liberal voting regimes. As labour was mobile, yardstick competition among the colonies was important for white labourers. $^{28}$

Table 1

Estimated English immigration to Virginia, 1607-1700

\begin{tabular}{|c|c|c|c|c|c|c|c|c|}
\hline \multicolumn{3}{|c|}{ Estimate 1} & \multicolumn{3}{|c|}{ Estimate 2} & \multicolumn{3}{|c|}{ Estimate 3} \\
\hline Period & Total & Annual & Period & Total & Annual & Period & Total & Annual \\
\hline $1607-24$ & 6,000 & 333 & & & & & & \\
\hline $1625-33$ & 3,000 & 333 & & & & & & \\
\hline $1634-40$ & 8,800 & 1,257 & $1630-40$ & 8,900 & 809 & 1636-39 & 4,738 & 1,185 \\
\hline $1641-50$ & 12,000 & 1,200 & $1640-50$ & 6,000 & 545 & $1640-49$ & 6,797 & 680 \\
\hline $1651-60$ & 18,500 & 1,850 & $1650-60$ & 11,600 & 1,055 & $1650-59$ & 18,836 & 1,884 \\
\hline $1661-70$ & 7,600 & 760 & $1660-70$ & 6,500 & 591 & $1660-69$ & 18,369 & 1,837 \\
\hline $1671-80$ & 7,400 & 740 & $1670-80$ & 8,100 & 736 & $1670-79$ & 13,867 & 1,387 \\
\hline \multirow[t]{3}{*}{$1681-1700$} & 18,200 & 910 & $1680-90$ & 7,900 & 718 & $1680-89$ & 10,401 & 1,040 \\
\hline & & & 1690-00 & 8,500 & 773 & $1690-99$ & 9,388 & 939 \\
\hline & $\Sigma 81,500$ & $\emptyset 867$ & & $\Sigma 57,500$ & $\varnothing 821$ & & $\Sigma 82,396$ & $\emptyset 1,177$ \\
\hline
\end{tabular}

Sources: Purvis (1999, p. 164), Menard (1988, p. 105), Craven (1971, pp. 14-16).

Notes: Estimate 1 uses the data from Purvis (1999). Estimate 2 uses the Virginia and Maryland data from Menard (1988) and subtracts the Purvis (1999) data for Maryland. Estimate 3 uses the headright data for Virginia from Craven (1971).

\footnotetext{
${ }^{28}$ English immigration to Virginia declined following the adoption of the tight voting regime in the $1700 \mathrm{~s}$. Although the data in Table 1 do not go beyond 1700, we can infer this drop in migration from information on land grants (or headrights) that were given to all free settlers and which increased with the number of servants or slaves they transported to the colony. In the last quarter of the $17^{\text {th }}$ century, the number of servants arriving in the colony was probably between 1,500 and 2,000 annually. However, by the early $18^{\text {th }}$ century, the number of new indentured labourers had decreased dramatically to only 100 per year (Wertenbaker, 1922, p. 135). Data from the militia muster walls covering the French and Indian war and the American Revolution assembled by Villaflor and Sokoloff (1982, p. 565) paint a similar picture. Only $20 \%$ of the Virginia military recruits were foreign-born at this time, a figure very similar to that in Massachusetts and more than three times lower than the respective figures in Pennsylvania and Delaware. Given the low number of foreign migrants and the out-migration of even Americanborn men, Virginia experienced a net population loss during this period. This rapid population decline, along with the rising prominence of the smaller landholding class, limited the opportunities for collective action by the disenfranchised, and further facilitated the adoption of less democratic political institutions in the colony.
} 
The liberal suffrage also initially benefited the political and economic elites. Edward Sandys, the Virginia Company treasurer from 1619 to 1624 , believed that a representative Assembly would allow the colonists to design effective policies encouraging immigration, which in turn would increase the prosperity of the colony and the Company (Perry and Cooper, 1959, p. 48; Bruce, 1910, p. 404). He advocated for attracting migrants through voting rights and land grants and within three years of becoming treasurer he had managed to populate the colony with more than 3,500 people, accounting for almost twice the immigration in the preceding ten years (Morgan, 1975, p. 98). The governor-who represented royal interestscontinued to convene the Assembly after the dissolution of the Company in 1624, even in the absence of explicit permission from the King. Like the planters, assemblymen had little interest in changing the liberal institutional arrangement. Both regular colonists and politicians lobbied King Charles I to recognise the General Assembly after he failed to explicitly allow for its continuation after 1624. From the King's perspective, the colonial government template was also profitable and useful. ${ }^{29}$

Why did this arrangement ultimately crumble? In the spirit of Stasavage (2002), our analysis highlights the role of changing political coalitions that reflected the socio-economic composition in the $17^{\text {th }}$ versus the $18^{\text {th }}$ century. For most of the $17^{\text {th }}$ century, society comprised planters and a large number of indentured servants (McCusker and Menard, 1991, p. 135). The planter-aristocrats included men who were former Virginia Company members or those who had inherited or acquired land, servants and political privileges. These members were also burgesses or held appointed positions such as councilmen, customs officers, surveyors and others. Along with servants still serving their indenture, freemen who had finished their terms but had not managed to set up their own farms comprised the poorest segment of society (Morgan, 1975, p. 225). However, upon gaining freedom, many former servants were able to start their own farm and sometimes even join the ranks of larger planters (Wertenbaker, 1922, pp. 41-43). As former servants became freeholders, they joined forces with the larger planters to push for a regime favouring freemen. As noted above, the voting restrictions first explicitly targeted indentured servants.

\footnotetext{
${ }^{29}$ The royal proclamation after the Virginia Company, which failed to make an allowance for the continuation of the Assembly, can be explained by the King's distraction and not by his hostility towards the colony's representative institutions (Billings, 2004, p. 12).
} 
In the late $-17^{\text {th }}$ and early- $18^{\text {th }}$ century, the number of small to medium-sized planterswho owned land and at most one servant-grew in importance (at the expense of landless freemen and indentured servants). By contrast, farmers without servants or slaves gradually declined in number and sank into poverty, as they were unable to compete with the more efficient large farms. The rising economic importance and political voice of small slave-holding farmers - along with the reduced demand for poor English workers-led to the emergence of a new strategic alliance, which prompted limiting the suffrage to only landholders and leaseholders. The new coalition of small and large landholders had slavery as the main unifying factor: black labour benefited not only large farmers who were now able to expand their estates and production, but also smaller tobacco growers who-while previously unable to afford indentured servants - could now acquire cheaper slaves (Wertenbaker, 1922, pp. 150-155). ${ }^{30}$ Rather than encouraging migration, this slave-holding coalition now cared about tobaccorelated issues such as diversification, trade centralisation and infrastructure provision (Kulikoff, 1986, pp. 78-79). ${ }^{31}$

Another attestation to the rising political influence of small farmers is that while the government prohibited landless freemen from serving on court juries, small landholders became more prominent in local politics, such as county government offices (Hening, 1823, Vol. 3, Act IV, p. 175). Further evidence pointing to the political importance of small freeholders is the fact that the specific size of the freehold required for voting was unspecified until 1736. This minimum freehold requirement provided three alternatives for voting: 100 acres of land (which was lowered to 50 acres in 1762), 25 acres and a house or a town house and a lot (Hening, 1820, Vol. 4, pp. 475-78). As McKinley (1905) points out, it is remarkable how those in power tailored the freehold requirement to reflect different classes (large and small) of Virginia's landholders (pp. 34-83).

A second pivotal shift concerned the bargaining and coalition-building between the governor and the House of Burgesses. Before the 1730s, factions friendly to and opposing the governor were at odds with each other in the House of Burgesses, thus pitting royal against colonial interests. Local leaders opposed the royal position on many colonial issues and did everything possible to defeat the governor-backed candidates at elections (Dinkin, 1977, p. 14).

\footnotetext{
${ }^{30}$ On average, such a small farmer held between one and five slaves (Table A2).

${ }^{31}$ This political transformation was also influenced by the particular structure of Virginia's Assembly. Although any voter could run for office, most of the candidates were rich, as the compensation of legislators was not particularly high and lasted only for the duration of Assembly sessions (Dinkin, 1977, p. 60).
} 
In the subsequent period, in part due to the clashes between the governor and council, the House of Burgesses emerged as the political institution with the greatest influence.

By changing the distribution of political power in the Assembly, the coalition shifts influenced the content and quantity of adopted legislation, thus reflecting the changing politicoeconomic interests. Until the mid-1670s, the House issued multiple acts regulating servantmaster relations, sometimes as many as six annually. In 1642, servants had the right to seek the support of the local commissioner-who was the head of the county court appointed by the governor and the council - and complain about "harsh or vnchristianlike vsage or otherways for want of diet, or convenient necessaryes" (Hening, 1823, Vol. 1, p. 255, Act XXII). Other acts also required masters to provide servants with decent clothing, food and lodging. To prevent the exploitation of indentured labourers, the Assembly issued statutes specifying the punishment that a master could enforce when a runaway servant was apprehended, such as the number of extra days that a servant had to serve (Smith, 1971, p. 266). Similarly, freed servants had to obtain a certificate of freedom upon completing service (Hening, 1823, Vol. 2, pp. 115$119,277-279,388,488)$. By contrast, the number of acts related to indentured servitude rapidly decreased in the last quarter of the $17^{\text {th }}$ century, following the restriction of Virginia's suffrage to freeholders. After the arrival of slavery in the early- $18^{\text {th }}$ century, legislation no longer pertained to only servants; rather, laws concerned both the few remaining servants and slaves. Rather than passing legislation to attract immigrants, the Assembly focused on resolving the common concerns of landholders, both large and small, such as the regulation of tobacco exports. To minimise agricultural risks, political leaders also sought to centralise trade by establishing towns, encourage diversification and control the quality and quantity of tobacco exported each year.

The powerful House of Burgesses accepted bottom-up input and views from the smaller freeholders and catered to their interests (Rainbolt, 1970, p. 422). Common planters made political demands and sought a responsive government, a trend that began with Bacon's rebellion of 1676. Political leaders understood that to prevent another rebellion and ensure social stability, they needed to pay more attention to the concerns of smaller landholders (Billings, 2004, p. 50). Importantly, the most successful pieces of legislation in $18^{\text {th }}$-century Virginia catered to the needs of small farmers and enlisted their support (Rainbolt, 1970, pp. 418-422). For example, the negative reactions to the Tobacco Inspection Act of 1730 - which favoured higher-quality tobacco produced by large planters - show the bargaining strength of small farmers. When rioting, burning tobacco warehouses and filing petitions with the House 
proved unsuccessful, small farmers voted out many of the Act's original supporters in the 1734 elections.

\section{Empirical analysis}

Our econometric analysis can only test the labour market hypothesis since bargaining and coalitions are challenging to measure quantitatively. While this is an important shortcoming, it is mitigated by the detailed analytic narrative presented in the previous section.

\subsection{Data}

While data for colonial Virginia are often incomplete or inconsistent, to the greatest extent possible we have attempted to reconcile data differences and check consistency using multiple sources. Although we have tried to be as thorough as possible in collecting and checking the data, we acknowledge that all tables and empirical results should be interpreted with caution.

\subsubsection{Dependent variable: Suffrage}

To measure political institutions, we rely on suffrage data coded from McKinley (1905) and used in Nikolova (2017). The data are cross-checked against other work, such as Rusk (2001), Dinkin (1977) and Brown and Brown (1964). For each colony and over time, the existence of various restrictions placed by colonial governments on the franchise- such as those related to tax-paying, residency or religion-is coded. The complete list of suffrage restrictions is provided in the Appendix Part 4.

For Virginia, we create and add up separate dummy variables capturing the existence of each suffrage restriction. We re-scaled the raw index (which ranges from 0 to 4 ) so that higher values indicate more liberal suffrage and lower values correspond to more restrictive suffrage. Therefore, to calculate the suffrage variable we first take the maximum value of this raw sum of suffrage restrictions across all colonies, which is $6.5 .^{32}$ This is undertaken so that we can compare the evolution of Virginia's franchise relative to this time-invariant maximum calculated for all colonies. We then subtract the Virginia raw suffrage index from 6.5 to obtain the franchise index used in the empirical analysis. The final index ranges from 6.5 (when no restrictions were imposed and the most liberal franchise regime prevailed) to 2.5 (when all four

\footnotetext{
${ }^{32}$ The fractional number (6.5) is due to the fact that in some colonies (excluding Virginia) voters were given the freedom to pick from two or more requirements to vote, which likely implied that the size of the electorate was larger than that in colonies which imposed only one of those restrictions. For instance, a colony which required electors to be both freeholders and to be literate imposed 2 restrictions, while a colony which gave a choice of either regulation imposed 0.5 restrictions. See the Appendix Part 4 for more details and alternative coding approaches.
} 
restrictions were imposed and a very restrictive political system was in place). Since periods that do not allow citizens to vote at all represent the most authoritarian institutional arrangement, these are assigned a suffrage value of 0 .

Table 2 shows the various suffrage restrictions in force in Virginia until 1775, as well as the value of the resulting suffrage index. For example, between 1619 and 1623 there were no restrictions upon voters, resulting in a suffrage value of $6.5(6.5-0)$. No one was eligible to vote between 1624 and 1627, which means that the franchise was coded as 0. Between 1658 and 1668, voters had to satisfy three requirements, with a resulting suffrage index of 3.5 (6.5$3)$.

Even though the reliability of the McKinley study was also confirmed by Stanley Engerman, ${ }^{33}$ it is likely that the data measure representative institutions with error. This should be partly mitigated by the fact that historians agree that the suffrage restrictions on the books were binding, suggesting that the franchise rules that we code should be highly correlated with those that were actually enforced (Dinkin, 1977, pp. 47-48; Rusk, 2001, p. 14). A more sophisticated suffrage index would also include information on the joint distribution of the characteristics on which the restrictions are based, although unfortunately such data are unavailable for any of the thirteen colonies. To address this for the case of Virginia, we experimented with several alternative coding schemes (described in more detail in Section 4.2 and the Appendix Part 4), which produced a suffrage index very highly correlated with that obtained using our original approach. Moreover, the suffrage index correlates reasonably well with fragmentary cross-colony suffrage extensiveness figures (Nikolova, 2017). Although admittedly we cannot claim to eliminate all sources of bias in our dependent variable, our multipronged approach makes us more confident that we are accounting for true differences in Virginia's representative institutions over time, rather than simply noise arising from a particular coding approach.

\subsubsection{Labour markets}

To capture the socio-demographic composition of colonial labour markets, we would ideally prefer data on the supply of and demand for different groups of labourers, such as indentured servants, free white labourers, family labourers and slaves. While such detailed data are unavailable for colonial Virginia, we have information on the share of the black population from Historical Statistics of the United States (2006). Since the major labour shock in the period

${ }^{33}$ This was done via personal communication. 
under study is the arrival of slavery, these data should capture labour movements in the colony reasonably well. As explained earlier, until the late- $17^{\text {th }}$ century slaves were largely unavailable, whereby Virginia's landowners had to rely on scarce workers from England.

We acknowledge that this proxy for labour market composition is imperfect. The share of the black population may well account for changes in the labour market arising from the substitution of whites with slaves, but is less accurate at capturing shifts simultaneously affecting both groups of workers (such as rising life expectancy) or happening within the group of white workers. Moreover, percent black does not allow us to distinguish between changes in labour supply as opposed to labour demand, or the number of demanded workers versus the number of supplied workers. The variable may also capture other factors, such as rising inequality after the arrival of slavery or racial tensions. We address these concerns in two ways. First, we experiment with an alternative measure of labour market composition: the ratio of Caribbean slave prices over sugar prices. Since the Caribbean was the largest slave market, setting prices for the rest of the New World, high Caribbean slave prices should reduce the number of new slaves in demand in the South. The effect of high Caribbean prices should be particularly strong when the price of sugar-the main Caribbean export crop-is low. In addition, we also control for white population density, which should proxy for white labour scarcity.

\subsubsection{Inequality}

Unfortunately, time-series inequality data for colonial Virginia and the rest of the twelve colonies are non-existent. To overcome this, we make use of an inequality proxy that is available for most of the colonial period: the percentage of Virginia's white male landless population relative to the population of all white males. We rely on several secondary sources, which we discuss in the Appendix. We expect that rises in inequality will be associated with an increase in the proportion of landless whites, while when incomes are equally distributed the share of the white landless population will be small. Clearly, our inequality proxy is less precise than contemporary inequality data. By focusing only on the share of white landless males, it ignores variations in income among the landed, women and (mostly enslaved) blacks. At the same time, neither of the latter two classes could vote until the $19^{\text {th }}$ and $20^{\text {th }}$ centuries, respectively, so such an omission is less problematic given that the distributive conflicts of interest during this period involved white males. Furthermore, it is possible that while the share 
of white landless males remained constant, income shares accruing to the bottom or top ten per cent of the population varied.

Nevertheless, there are several reasons why the percentage white landless variable should capture at least some of the variation in Virginia's income distribution. Historians agree that land - through its use for the production of tobacco — was the major determinant of income and wealth in colonial Virginia and the thirteen colonies more generally (Jordan 2002, pp. 8485; Risch 1937, pp. 5-6). As a result, the main class division in Virginia was between landed elites and landless whites, with the latter predominantly comprising indentured servants or newly-freed labourers. The wealth of colonial elite - amassed from the very beginning through land grants and tax breaks granted by the Crown-changed little over time. In addition, the share of the largest land-owning class (middle farmers owning between 100 and 500 acres) remained relatively constant; for instance, data from South Carolina indicate that around 60 percent of landowners held between 100 and 500 acres throughout the period under study (Cooper, 2000, pp. 6-7). As a result, taking into account those marginal farmers who shift from landlessness to owning land (and vice versa) should closely track changes in the overall income distribution. We provide additional evidence on the suitability of the inequality measure in the Appendix (Parts 3 and 4). ${ }^{34}$

\subsubsection{Additional controls}

Following Acemoglu et al. (2001), we use data on colonial urbanisation and white population density (both of these measures exclude blacks) to proxy economic development. ${ }^{35}$ Controlling for urbanisation is also important for ruling out concerns that a high percentage landless may be driven by the rise of cities and the decline of agriculture, rather than by an increase in income

\footnotetext{
${ }^{34}$ Furthermore, the literature has documented a positive correlation between inequality in income and in land. For instance, in the cross-country setting (for the period 1950-1979), Boix (2003) finds correlation coefficients in the range of 0.66-0.75 (see also Ramcharan (2010) and Vanhanen (2002)). Turning to the cross-colony sample and looking beyond the colonial period, we can exploit land distribution data for the American states covering 1860 to 1920, the earliest period for which such data are available. While there is no information on the percentage of the population with no landholdings, the number of farms under 10 acres should approximate the share of those owning no land (farm size in the 19th century US ranged from 41 to 468 acres, with a mean of 175 acres). The correlation between the proportion of farms under 10 acres and the land Gini coefficient in the cross-colony sample is 0.589 , which again suggests that percentage landless should account for a non-trivial proportion of the variation in the income distribution. Similarly, percentage white landless correlates well with the share of taxable wealth of the top $10 \%$ of the population (in the cross-colony sample) (Nikolova, 2017). In the Appendix, we also examine several other inequality proxies, such as data on farm sizes and on the distribution of adult workers and slaves. Although the latter cannot be used to build a long time series, relying on several inequality measures helps us to build a consistent picture of the income distribution in colonial Virginia.

${ }^{35}$ See Boix (2011) for a review of the literature on the link between economic development and democratisation.
} 
inequality. We also include a linear year trend in all regressions. Further data details are available in the Appendix.

\subsubsection{Graphical evidence}

Table 2 provides details on the type and number of suffrage restrictions in colonial Virginia, along with the resulting value of the suffrage index used in the regressions. The year groups in the table follow the periods in which a particular set of franchise rules was in force. Although there were few restrictions on the franchise during most of the $17^{\text {th }}$ century, voting became more restrictive in the early-1700s. Representative institutions were remarkably stable for the first fifty years or so, with higher volatility around the mid- $17^{\text {th }}$ century, precisely when declined mortality made attracting indentured servants less pressing. We observe a clear pattern, with a universal male franchise until the mid- $17^{\text {th }}$ century, followed by a suffrage restricted to freemen (sometimes along with other qualifications, such as residency) and a freehold requirement (progressively combined with other restrictions, such as residency, religion or race) from the late- $17^{\text {th }}$ century until 1775 .

\section{Table 2}

Suffrage in Virginia, 1606 - 1775

\begin{tabular}{|c|c|c|c|c|c|c|c|c|c|c|c|}
\hline Years & 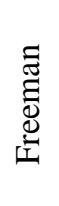 & 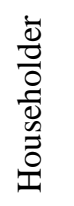 & $\begin{array}{l}\frac{7}{0} \\
\frac{0}{0} \\
0 \\
0\end{array}$ & $\dot{\Xi}$ & 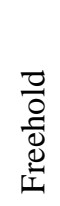 & $\stackrel{\underset{\oplus}{\oplus}}{\stackrel{x}{\sigma}}$ & 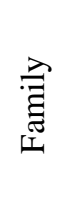 & 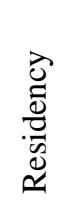 & 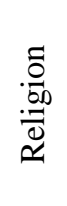 & $\begin{array}{l}\ddot{\Xi} \\
\check{\mathscr{J}}\end{array}$ & $\begin{array}{c}\text { Suffrage } \\
\text { index }\end{array}$ \\
\hline $1606-1618$ & $x$ & $x$ & $x$ & & $x$ & $x$ & $x$ & $x$ & $x$ & $x$ & 0 \\
\hline $1619-1623$ & & & & & & & & & & & 6.5 \\
\hline $1624-1627$ & $x$ & $x$ & $x$ & & $x$ & $x$ & $x$ & $x$ & $x$ & $x$ & 0 \\
\hline $1628-1654$ & & & & & & & & & & & 6.5 \\
\hline $1655-1655$ & & $\checkmark$ & & & & & $\checkmark$ & & & & 4.5 \\
\hline $1656-1657$ & $\checkmark$ & & & & & & & & & & 5.5 \\
\hline $1658-1668$ & $\checkmark$ & & & & & $\checkmark$ & & $\checkmark$ & & & 3.5 \\
\hline $1669-1669$ & $x$ & $x$ & $x$ & & $x$ & $x$ & $x$ & $x$ & $x$ & $x$ & 0 \\
\hline $1670-1683$ & & $\checkmark$ & $\checkmark$ & & & & & & & & 4.5 \\
\hline $1684-1698$ & $\checkmark$ & $(\sqrt{ })$ & $(\sqrt{ })$ & & & & & & & & 5.5 \\
\hline $1699-1704$ & & & $\checkmark$ & & & & & & $\checkmark$ & & 4.5 \\
\hline $1705-1735$ & & & $\checkmark$ & & & & & $\checkmark$ & $\checkmark$ & $\checkmark$ & 2.5 \\
\hline $1736-1775$ & & & $\checkmark$ & & $\checkmark$ & & & & $\checkmark$ & $\checkmark$ & 2.5 \\
\hline
\end{tabular}

Source: McKinley (1905).

Notes: Check-marks indicate which criteria voters had to satisfy in the respective period. Check-marks in parentheses indicate restrictions which were formally in place, but were not enforced as there was no punishment for irregular voting. Crosses stand for years without an elected Assembly. Since only freemen could possess land 
or property, we omit the coding for the freemanship restriction once restrictions for householding or freeholding are in place. See the text for more details.

As elaborated in Section 2, labour market dynamics provide only a partial explanation for the patterns in colonial Virginia's franchise laws. Changes in labour markets in turn affected the influence of social coalitions, which affected bargaining within parliament to adopt different suffrage laws. Our argument suggests that the variation in representative institutions will be closely related to the racial composition of the labour market. Indeed, Figure 1 demonstrates a close correlation between the suffrage index and the share of Virginia's black population: franchise law becomes progressively more restrictive as the share of blacks increases. In addition, identifying this relationship is aided by the slow-moving nature of Virginia's income inequality in the colonial period, which is confirmed in Figure A1. ${ }^{36}$

\section{Suffrage index}

\section{Labour}

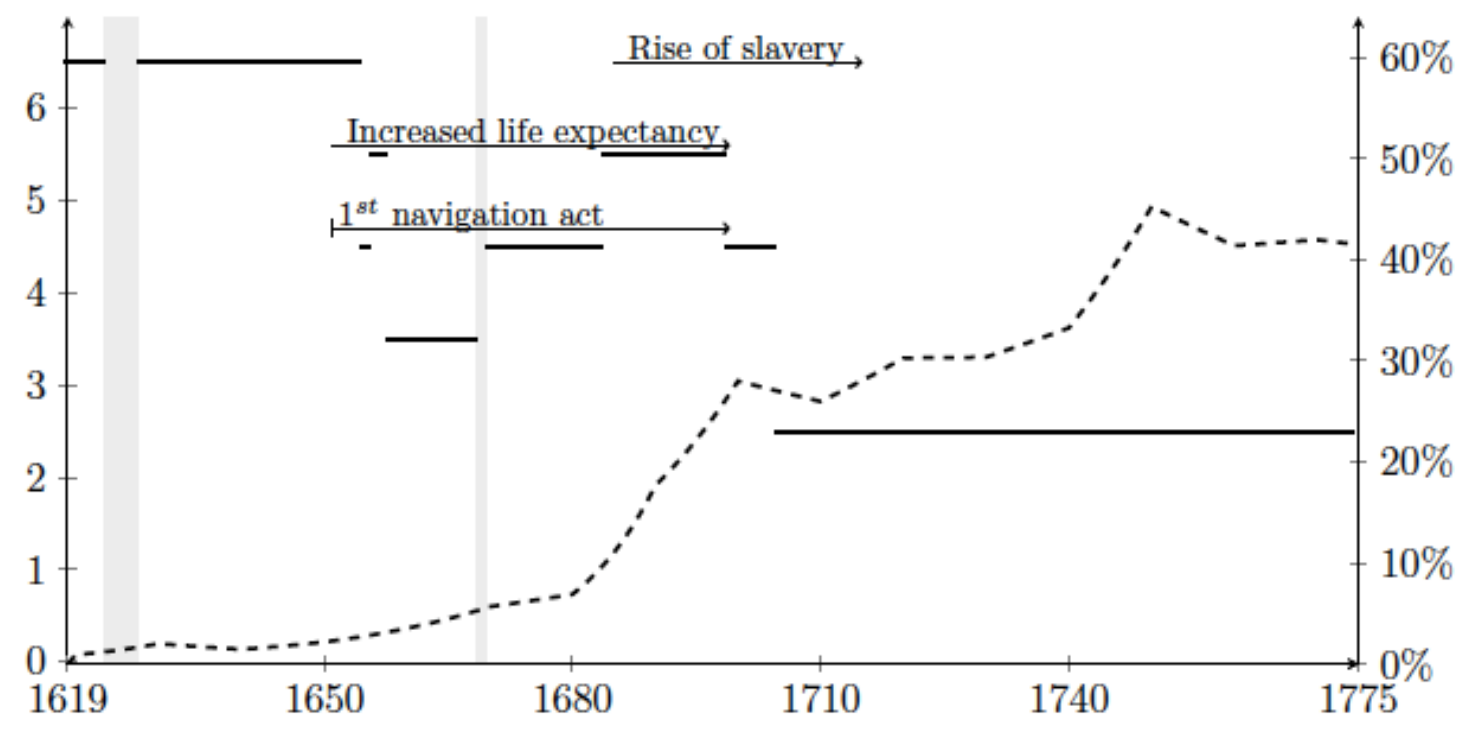

$$
\text { - Suffrage index --- Labour (\% black) }
$$

Fig. 1. Suffrage and labour markets in Virginia

Notes: The shaded grey areas indicate periods without an elected Assembly.

\subsection{Econometric analysis}

Based on our labour markets hypothesis, Virginia's representative institutions will be affected by the racial composition of the labour market, inequality and economic development. We expect that the higher share of blacks and higher inequality will lead to worse representative institutions. We also hypothesise that economic development (proxied by urbanisation and

\footnotetext{
${ }^{36}$ Figure A2 compares the evolution of franchise institutions in Virginia to those in the South and the North.
} 
population density) is positively associated with the quality of Virginia's representative institutions.

In Table 3, we regress the suffrage index on its lagged value, our proxy for labour market structure (the share of Virginia's black population), as well as controls for inequality (measured as percent white landless), differenced urbanisation, differenced population density and a linear trend. Unreported results without a linear trend are very similar to those presented below. We include urbanisation and population density in differences as both variables have a unit root in levels. ${ }^{37}$ Due to data availability, we use an annual data set. Since the inequality data start in 1682, our annual data set includes 93 observations. The results are similar when all variables are averaged over three years, although the number of observations drops to only 31 (Table A3).

Table 3

Suffrage in colonial Virginia, 1619-1775 (annual data)

\begin{tabular}{|c|c|c|c|c|c|c|c|}
\hline & $\begin{array}{c}(1) \\
\text { OLS } \\
\text { Base }\end{array}$ & $\begin{array}{c}\text { (2) } \\
\text { OLS } \\
\text { Slave sugar } \\
\text { ratio }\end{array}$ & $\begin{array}{l}(3) \\
\text { Tobit }\end{array}$ & $\begin{array}{c}\text { (4) } \\
\text { OLS } \\
\text { Suffr.Dinkin }\end{array}$ & $\begin{array}{c}\text { (5) } \\
\text { OLS } \\
\text { Suffr.Ordinal }\end{array}$ & $\begin{array}{c}\text { (6) } \\
\text { OLS } \\
\text { Suffr.binary }\end{array}$ & $\begin{array}{l}(7) \\
\text { OLS } \\
\text { Drop } \\
\text { years }\end{array}$ \\
\hline Lagged Suffrage & $\begin{array}{l}0.947^{* * *} \\
(0.0255)\end{array}$ & $\begin{array}{l}0.949^{* * *} \\
(0.0260)\end{array}$ & $\begin{array}{l}1.269^{* * *} \\
(0.112)\end{array}$ & $\begin{array}{l}0.947^{* * *} \\
(0.0338)\end{array}$ & $\begin{array}{l}0.955^{* * *} \\
(0.0332)\end{array}$ & $\begin{array}{l}0.820^{* * *} \\
(\mathrm{O} .111)\end{array}$ & $\begin{array}{l}0.947^{* * *} \\
(0.0255)\end{array}$ \\
\hline Labour (\%black) & $\begin{array}{l}-3.027^{* *} \\
(1.516)\end{array}$ & & $\begin{array}{l}-\mathbf{3 . 4 1 3} \\
(2.087)\end{array}$ & $\begin{array}{c}-\mathbf{3 . 8 1 1}^{* *} \\
(1.867)\end{array}$ & $\begin{array}{c}-\mathbf{3 . 8 0 4}^{* *} \\
(1.903)\end{array}$ & $\begin{array}{c}\mathbf{- 1 . 8 0 4} \\
(1.121)\end{array}$ & $\begin{array}{c}-3.079^{*} \\
(1.558)\end{array}$ \\
\hline $\begin{array}{l}\text { Labour (slave-sugar } \\
\text { Caribb.) }\end{array}$ & & $\begin{array}{c}\mathbf{0 . 3 1 3}^{* *} \\
(0.154)\end{array}$ & & & & & \\
\hline $\begin{array}{l}\text { Inequality (\% white } \\
\text { 1.less) }\end{array}$ & $\begin{array}{l}2.004^{* *} \\
(0.983)\end{array}$ & $\begin{array}{c}0.288 \\
(0.496)\end{array}$ & $\begin{array}{l}8.861^{* *} \\
(3.412)\end{array}$ & $\begin{array}{l}2.341^{* *} \\
(1.155)\end{array}$ & $\begin{array}{l}1.658^{*} \\
(0.960)\end{array}$ & $\begin{array}{c}0.270 \\
(0.282)\end{array}$ & $\begin{array}{l}2.017^{* *} \\
(0.990)\end{array}$ \\
\hline Urb. diff & $\begin{array}{c}13.69 \\
(16.86)\end{array}$ & $\begin{array}{c}17.89 \\
(17.33)\end{array}$ & & $\begin{array}{c}13.82 \\
(16.73)\end{array}$ & $\begin{array}{c}16.87 \\
(16.39)\end{array}$ & $\begin{array}{c}0.306 \\
(3.489)\end{array}$ & $\begin{array}{c}13.83 \\
(16.89)\end{array}$ \\
\hline Pop. dens. diff & $\begin{array}{l}-0.119 \\
(0.0886)\end{array}$ & $\begin{array}{l}-0.133 \\
(0.0889)\end{array}$ & $\begin{array}{l}-0.134 \\
(0.156)\end{array}$ & $\begin{array}{l}-0.121 \\
(0.0879)\end{array}$ & $\begin{array}{l}-0.106 \\
(0.0882)\end{array}$ & $\begin{array}{c}-0.00975 \\
(0.0195)\end{array}$ & $\begin{array}{l}-0.116 \\
(0.0885)\end{array}$ \\
\hline Year control & $\checkmark$ & $\checkmark$ & $\checkmark$ & $\checkmark$ & $\checkmark$ & $\sqrt{ }$ & $\checkmark$ \\
\hline Observations & 93 & 93 & 93 & 93 & 93 & 93 & 92 \\
\hline Mean suffrage & 3.414 & 3.414 & 3.414 & 3.586 & 2.237 & 0.161 & 3.424 \\
\hline$R^{2}$ & 0.938 & 0.935 & 0.937 & 0.950 & 0.950 & 0.874 & 0.938 \\
\hline
\end{tabular}

Notes: All independent variables are lagged by one period (one year). A linear trend is used as "Year control". Column (7) drops the year 1775. We omit the urbanisation control in the Tobit procedure. Robust standard errors are in parentheses. ${ }^{* * *} \mathrm{p} \leq 0.01,{ }^{* *} \mathrm{p} \leq 0.05,{ }^{*} \mathrm{p} \leq 0.1$.

Column 1 presents our baseline specification, showing that a 10 percentage point increase in the share of the black population is associated with a deterioration in the suffrage by around 0.303 points, or $8.9 \%$ relative to the sample mean (shown at the bottom of the table). The long-term effect of labour is even stronger: around $16.7 \%$, relative to the mean of the

\footnotetext{
${ }^{37}$ Unreported results are robust to dropping urbanisation and population density from the regressions. Standard unit-root tests indicate no unit roots in suffrage, while unit-root tests allowing for one or two endogenous structural breaks (conducted below) reject the null of a unit root in percent black and inequality. Tests without a structural break instead show that the two variables do have a unit root, though they are cointegrated. The augmented DurbinWatson test shows that serial correlation is not a concern in the regressions.
} 
dependent variable. ${ }^{38}$ Contrary to our theoretical priors, a 10 percentage point increase in inequality actually improves the franchise by around 5.9\% in the short term and around $11.1 \%$ in the long term. In column 2, we instead measure labour by the ratio of Caribbean slave prices over sugar prices. The point estimate suggests that periods in which slaves were relatively expensive (for Caribbean as well as North American farmers) were associated with better representative institutions. A one-standard deviation increase in the average slave price improves the suffrage by around 2.4 restrictions, or around $70 \%$ relative to the mean, which is a very strong effect. ${ }^{39}$

In column 3, we run a Tobit specification in which periods with no elections are coded as the minimum suffrage value observed only in the Virginia sample (2.5), rather than as 0 . The results are similar to those in column 1, albeit less precisely estimated. In the next three columns, we experiment with several different operationalisations of the franchise. In column 4, we keep only those restrictions identified by Dinkin (1977) as important (dropping restrictions for freemanship, formal patenting of lands, householding and being a good person). Next, we use an ordinal approach to code the suffrage variable. ${ }^{40}$ In column 6 , we recode the suffrage index as a binary variable, which takes a value of 0 if any of the following restrictions are in force: income or property, freeholding, the existence of minimum freeholding or property, tax, residency and religion, and 1 otherwise. In all three cases, the coefficient on labour is negative and significant and in two of the specifications, larger than the baseline specification. In column 7, we drop the year 1775 (since the American Revolution was already under way then) and again obtain similar results.

The coefficient estimate on inequality (measured as percent white landless) is positive and significant, indicating that higher inequality is correlated with better representative institutions. As inequality changed little during the colonial period, the regression coefficient may simply capture small changes in the percent landless variable. Alternatively, it is possible that the inequality measure also accounts for other factors, such as the strength of revolutionary

\footnotetext{
${ }^{38}$ Following Boix (2011), the long-term effect is obtained by dividing the coefficient on labour by the quantity (1coefficient on lagged suffrage).

${ }^{39}$ The mean Caribbean slave price during the colonial period was around 27.4 pounds sterling, with a standard deviation of 7.7.

${ }^{40}$ Rather than building a suffrage index which is based on the sum of all suffrage restrictions (subtracted from the maximum number of restrictions in the sample, 6.5), this coding approach aims to order groups of restrictions based on their relevance, following Przeworski (2009). We end up with a raw suffrage index ranging from 0 to 6 , which is then subtracted from the maximum number of restrictions in the sample (6.5) to obtain the ordinal suffrage index used in the regressions. For instance, periods when voters had to satisfy restrictions for freeholding, residency, religion and race are given a raw suffrage value of 5, and the resulting suffrage index is $1.5(6.5-5)$. Periods when voters had to be freeholders and of a particular religion are given a raw suffrage value of 3 , and the resulting suffrage index is 3.5 (6.5-3). See the Appendix for more details.
} 
threats. We discuss these concerns and conduct a battery of robustness checks in the Appendix. The regressions indicate that there is little effect of urbanisation or population density on Virginia's suffrage. ${ }^{41}$

\section{Conclusion}

What leads to changes in the franchise? We offer a novel two-part argument. On the one hand, we argue that franchise laws will respond to labour market dynamics. When labour is scarce, voting rights serve to attract scarce migrant labour as they resolve contracting issues and prevent migrant exploitation. When labour market pressures subside, rulers restrict the suffrage as liberal political institutions are no longer optimal. We illustrate this part of the theory using an analytic narrative and econometric evidence from colonial Virginia. Nevertheless, this framework has three main limitations: first, it assumes that economic interests automatically translate into political outcomes concerning the suffrage; second, it does not elucidate why the newly disenfranchised would not rebel; and third, it fails to account for suffrage fluctuations, which were often at odds with the more general trend.

We address these criticisms by arguing that labour market shifts prompted the emergence of three different societal coalitions that influenced politics. In the early- $17^{\text {th }}$ century, planters joined forces with migrant labourers whom they needed to generate profit, resulting in a regime in which the servants could vote. In the middle of the $17^{\text {th }}$ century, the increased number of freed former servants and existing freemen led to a new coalition of freemen, which excluded servants from the franchise. Finally, the arrival of slavery in the late$17^{\text {th }}$ and early- $18^{\text {th }}$ century allowed for the economic prosperity of small and large farmers alike, who joined forces to push for a regime favouring freeholders. We show that these new coalitions determined the political process and the bargaining among elected and appointed politicians in the colonial government and influenced the content and extent of legislation.

We anticipate at least two objections to our analysis. Some will argue that the data may not be sufficiently reliable to support causal inference. Although historical data are notoriously error-prone, we believe that our transparent data collection effort-along with the combination of econometric evidence and an analytic narrative-makes such a critique less convincing. A related criticism could be that our reliance on a single colony fails to provide sufficient variation to test the causal mechanisms that we have in mind, whereby one should instead turn to cross-

\footnotetext{
${ }^{41}$ The fact that the coefficient estimate for urbanisation is statistically insignificant could be due to lack of yardstick competition (Congleton, 2011) among cities and towns in the Virginia system. In addition, the production of crops such as rice and tobacco made the establishment of large cities unnecessary (McCusker and Menard, 1991).
} 
colony evidence. However, the historical episode that we exploit is unique precisely because we observe multiple changes in political institutions, which is rare even in large cross-country studies. While our work parallels the cross-colony analysis in Nikolova (2017), our finegrained, mixed-method approach and the rich analytic narrative in particular give us more traction in identifying the causal mechanism at work. We are able to rule out the confounding effect of inequality on the franchise and examine the formation of political coalitions that were ultimately responsible for democratic reversal in Virginia.

A second point relates to the external validity of the proposed mechanisms. Although the labour market proposition was inspired by colonial America, the argument could be used to explain other instances of institutional change. For example, to attract skilled German migrants, $12^{\text {th }}$-century Eastern European lords granted them political rights that were not only greater than those of the local population, but also more extensive than the provisions of German law (Blum, 1957, p. 814-819). Likewise, female enfranchisement in Western Europe coinciding with the rise in female factory employment after World War I made male workers scarce. Baland and Robinson (2008) demonstrate that prior to the introduction of the secret ballot in 1958, Chilean landlords controlled the votes of rural inquilinos. While rural workers enjoyed relatively good working conditions, the large supply of migratory labourers meant that these benefits could be taken away at any point. In addition, the more general version of the bargaining model that we offer here-namely Congleton's constitutional bargaining and exchange model (2011), which describes the shift from an authoritarian King to King-and-council templates - helps to explain a number of institutional developments in Western Europe as well as Japan.

However, we must emphasise that we do not claim to provide a "one-fit-all" theory. For instance, Africa's labour scarcity may have shaped the continent's economics and politics for the wore (Herbst, 2000; Fenske, 2013). While revolutionary threats played a marginal role in Virginia, Aidt and Jensen (2014) show that this mechanism was important in Western Europe. Nonetheless, we hope to have shown that history can have unexpected but important lessons for how we evaluate — and apply_existing theories of political institutions.

\section{Acknowledgements}


The authors are very thankful to two anonymous referees and the Editor (Toke Aidt) for many comments and suggestions, which helped to improve the quality and exposition of this paper. We would like to thank Carles Boix, Grigore Pop-Eleches, Nolan McCarty and Jeff Hammer for many helpful discussions, as well as participants at EEA-Tolouse 2014, Ben Ansell, Milena Djourelova, John Gerring, Sergei Guriev, Simon Hess and Joachim Voth. It would be remiss if we failed to acknowledge help with procuring articles for the literature review from Margard Ody, data help from Georgios Tassoukis, and research assistance from Daria Golokhvastova. All errors remain our own. The views expressed in this paper are those of the authors only (in a personal capacity) and not of the EBRD. Richard Forsythe provided copy-editing support.

\section{Funding Sources}

This research did not receive any specific grant from funding agencies in the public, commercial, or not-for-profit sectors. 


\section{References}

Acemoglu, D., S. Johnson, and J. A. Robinson (2001): "The Colonial Origins of Comparative Development: An Empirical Investigation,” American Economic Review, 91, 1369-1401.

Acemoglu, D. and J. A. Robinson (2006): Economic Origins of Dictatorship and Democracy, Cambridge University Press.

Aidt, T. and P. Jensen (2014): "Workers of the World, Unite! Franchise Extensions and the Threat of Revolution in Europe, 1820-1938," European Economic Review.72, 52-75.

Aidt, T. S. and R. Franck (2015): "Democratization under the threat of revolution: evidence from the great reform act of 1832," Econometrica, 83, 505-547.

Allen, R. C., T. E. Murphy, and E. B. Schneider (2012): "The Colonial Origins of the Divergence in the Americas: A Labor Market Approach," Journal of Economic History, 72, 863-894.

Ansell, B. and D. Samuels (2010): "Inequality and Democratization: A Contractarian Approach,” Comparative Political Studies, 43, 1543-1574.

Baland, J.-M. and J. A. Robinson (2008): "Land and Power: Theory and Evidence from Chile," American Economic Review, 98, 1737-65.

Bates, R. H., A. Greif, M. Levi, J.-L. Rosenthal, and B. Weingast (1998): Analytic Narratives, Princeton Paperbacks, Princeton University Press.

Bertocchi, G. and C. Strozzi (2008): "International Migration and the Role of Institutions," Public Choice, 137, 81-102.

Billings, W. M., 2004. A Little Parliament. The Library of Virginia, Richmond, Virginia.

Blum, J. (1957): “The Rise of Serfdom in Eastern Europe," American Historical Review, 807836.

Boix, C. (2003): Democracy and Redistribution, Cambridge University Press.

(2011): "Democracy, Development, and the International System," American Political Science Review, 105, 809-28.

Bourguignon, F. and T. Verdier (2000): "Oligarchy, Democracy, Inequality and Growth," Journal of Development Economics, 62, 285-313.

Braun, S. and M. Kvasnicka (2013): "Men, Women, and the Ballot: Gender Imbalances and Suffrage Extensions in the United States," Explorations in Economic History, 50, 405-426.

Breen, T. H. (1973): “A Changing Labor Force and Race Relations in Virginia 1660-1710," Journal of Social History, 7, 3-25.

Brown, R. E., \& Brown, B. K. T. (1964). Virginia, 1705-1786: Democracy Or Aristocracy? East Lansing: Michigan State University Press. 
Browne-Marshall, G. J. (2013). Race, Law and American Society. New York and Oxon: Routledge.

Bruce, P. (1910): Institutional History of Virginia in the Seventeenth Century, G.P. Putnam's sons.

Bushman, R. L. (1963). English Franchise Reform in the Seventeenth Century. The Journal of British Studies, 3(01), 36-56.

Chandler, J. A. C. (1901). The history of suffrage in Virginia. Baltimore, MD: Johns Hopkins Press.

Chute, M. (1969): The First Liberty: A History of the Right to Vote in America, 1619-1850,

Dutton.

Congleton, R. D. (2011): Perfecting Parliament, Cambridge University Press.

(2012): "Democracy in America: Labor Mobility, Liberalism, and Constitutional Reform," Working paper.

Cooper, W. J. (2000): Liberty and Slavery: Southern Politics to 1860, Univ of South Carolina Press.

Craven, W. (1971): White, Red, and Black: The Seventeenth-Century Virginian, James W. Richard lectures in history, University Press of Virginia.

Dinkin, R. J. (1977): Voting in Provincial America: A Study of Elections in the Thirteen Colonies, 1689-1776, Greenwood Press.

Dougherty, K. L. and J. C. Heckelman (2008): "Voting on Slavery at the Constitutional Convention," Public Choice, 136, 293-313.

Earle, C. (1979). Environment, Disease and Mortality in Early Virginia. Journal of Historical Geography, 5(4), 365-390.

Evans, E. G. (2009). A "Topping People": The Rise and Decline of Virginia's Old Political Elite, 1680-1790. Charlottesville and London: University of Virginia Press.

Engerman, S. L. and K. L. Sokoloff (2000): "History Lessons: Institutions, Factors Endowments, and Paths of Development in the New World," Journal of Economic Perspectives, 14, 217-232.

Fenske, J. (2013): “Does Land Abundance Explain African Institutions?” Economic Journal, 123, 1363-1390.

Fleck, R. K. and F. A. Hanssen (2006): "The Origins of Democracy: A Model with Application to Ancient Greece," Journal of Law and Economics, 49, 115-146.

Freeman, J. R. and D. P. Quinn (2012): “The Economic Origins of Democracy Reconsidered," American Political Science Review, 106, 58-80.

Galenson, D. W. 1984. The rise and fall of indentured servitude in the Americas: an economic analysis. The Journal of Economic History, 44(01), 1-26. 
Games, A. (1999): Migration and the Origins of the English Atlantic World, vol. 133, Harvard University Press.

Glaeser, E. L. and A. Shleifer (2005): "The Curley Effect: The Economics of Shaping the Electorate," Journal of Law, Economics, and Organization, 21, 1-19.

Grubb, F. (2003): "Creating the US Dollar Currency Union, 1748-1811: A Quest for Monetary Stability or a Usurpation of State Sovereignty for Personal Gain?" American Economic Review, 1778-1798.

Hatch, C. E. (1956). America's Oldest Legislative Assembly \& Its Jamestown Statehouses: US Department of the Interior, National Park Service.

Haggard, S. and R. R. Kaufman (2012): "Inequality and Regime Change: Democratic Transitions and the Stability of Democratic Rule," American Political Science Review, 106, 495-516.

Hening, W. W. (1819-1823): The Statutes at Large: Being a Collection of All the Laws of Virginia, from the First Session of the Legislature, in the Year 1619, R. \& W. \& G. Bartow.

Herbst, J. (2000): States and Power in Africa: Comparative Lessons in Authority and Control, Princeton University Press.

Hicks, D. L. (2013): "War and the political zeitgeist: Evidence from the history of female suffrage," European Journal of Political Economy, 31, 60-81.

Historical Statistics of the United States (2006): "Part E, Government and International Relations," in Colonial Statistics, Millennial Edition Online, Cambridge University Press, ed. by R. Sutch and S. Carter.

Jordan, D. W. (2002): Foundations of Representative Government in Maryland, 1632-1715, Cambridge University Press.

Keefer, P. (2007): "Clientelism, Credibility, and the Policy Choices of Young Democracies," American Journal of Political Science, 51, 804-821.

Klein, R. S., 2004. A Population History of the United States. Second Edition. New York: Cambridge University Press.

Kolp, J. G. (1998). Gentlemen and Freeholders: Electoral Politics in Colonial Virginia. Baltimore and London: Johns Hopkins University Press.

Kulikoff, A. (1986): Tobacco and Slaves: The Development of Southern Cultures in the Chesapeake, 1680-1800, University of North Carolina Press.

Limongi, F. and A. Przeworski (1997): "Modernization: Theories and Facts," World Politics, 49, 155-183.

Lizzeri, A. and N. Persico (2004): "Why Did the Elites Extend the Suffrage? Democracy and the Scope of Government, with an Application to Britain's "Age of Reform"," Quarterly Journal of Economics, 119, 707-765. 
Llavador, H. and R. J. Oxoby (2005): "Partisan Competition, Growth, and the Franchise," Quarterly Journal of Economics, 120, 1155-1189.

McCusker, J. and R. Menard (1991): The Economy of British America, 1607-1789, Needs and Opportunities for Study Series, Institute of Early American History and Culture.

McGuire, R. A. and P. R. Coelho (2011): Parasites, Pathogens, and Progress, MIT Press.

McGuire, R. A. and R. L. Ohsfeldt (1989): "Self-Interest, Agency Theory, and Political Voting Behavior: The Ratification of the United States Constitution," American Economic Review, 219-234.

McKinley, A. E. (1905): The Suffrage Franchise in the Thirteen English Colonies in America, Ginn \& co., Boston.

Menard, R. (1988): "British Migration to the Chesapeake Colonies in the Seventeenth Century," in Colonial Chesapeake Society, ed. by P. D. M. Lois Green Carr and J. B. Russo, University of North Carolina Press.

Morgan, E. S. (1975): American Freedom, American Slavery: The Ordeal of Colonial Virginia, W. W. Norton, New York.

Morgan, E. S. (2005). American Freedom, American Slavery: The Ordeal of Colonial Virginia. New York and London: History Book Club by arrangement with WW Norton \& Company, Inc (1646).

Nikolova, E. (2017): "Destined for Democracy? Labour Markets and Political Change in Colonial British America,” British Journal of Political Science, 47(1), 19-45.

North, D. C. and B. R. Weingast (1989): "Constitutions and Commitment: The Evolution of Institutions Governing Public Choice in Seventeenth-Century England," Journal of Economic History, 49, 803-832.

Officer, L. H. (2008): “What Were the UK Earnings and Prices Then?” Measuring Worth. Com. Perry, R. and J. Cooper (1959): Sources of Our Liberties: Documentary Origins of Individual Liberties in the United States Constitution and Bill of Rights, American Bar Foundation Series, New York University Press.

Pope, J. G. (1997): “Labour's Constitution of Freedom,” Yale Law Journal, 941-1031.

Przeworski, A. (2009): "Conquered or Granted? A History of Suffrage Extensions," British Journal of Political Science, 39, 291-321.

Purvis, T. L. (1999): Colonial America to 1763, Infobase Publishing.

Rainbolt, J. C. (1970): "The Alteration in the Relationship between Leadership and Constituents in Virginia, 1660 to 1720," William and Mary Quarterly: A Magazine of Early American History and Culture, 411-434.

Ramcharan, R. (2010): "Inequality and Redistribution: Evidence from US Counties and States, 1890-1930," Review of Economics and Statistics, 92, 729-744. 
Risch, E. (1937): "Encouragement of Immigration: As Revealed in Colonial Legislation," The Virginia Magazine of History and Biography, 45, 1-10.

Rusk, J. G. (2001): A Statistical History of the American Electorate, University of Chicago.

Seghezza, E. (2015): "Fiscal capacity and the risk of sovereign debt after the Glorious Revolution: A reinterpretation of the North-Weingast hypothesis," European Journal of Political Economy, 38, 71-81.

Smith, A. E. (1971): Colonists in Bondage: White Servitude and Convict Labor in America 1607-1776, W. W. Norton, New York.

Stasavage, D. (2002): "Credible Commitment in Early Modern Europe: North and Weingast Revisited," Journal of Law, Economics, and Organization, 18, 155-186.

Vanhanen, T. (2002): Prospects of Democracy: A Study of 172 Countries, Routledge.

Villaflor, G. C. and K. L. Sokoloff (1982): "Migration in Colonial America: Evidence from the Militia Muster Rolls,” Social Science History, 6, 539-570.

Ward, H. M. (1991): Colonial America, 1607-1763, London: Pearson College Division.

Wertenbaker, T. J. (1922): The Planters of Colonial Virginia, Princeton and London: Princeton University Press and Oxford University Press. 